beyond helping these men to think of things other than evil ones. There is no need to organize such efforts. The more informal they are the better. Dr Ramsbottom suggests that any fellow who is prepared to help in this direction should get into touch with the Y.M.C.A. or similar organization at the nearest camp; or with the padres at the military hospitals. Here they will find a knowledge of individuals which is amazing, and an offer to talk to one or two men or to give a lecture on some aspect of biology which has a popular appeal will invariably be accepted.

\section{Chair of Electrical Engineering, Birmingham}

THE chair of electrical engineering in the University of Birmingham, vacated by the resignation of Prof. B. L. Goodlet, has been filled by the appointment of Dr. Cecil Dannatt. Dr. Dannatt has had many years experience with the Metropolitan-Vickers Electrical Co., Ltd., at Manchester, especially in the Research Department, where he has for some time been in charge of the Electrical and Magnetic Laboratory. His work has brought him into close contact with various branches of the industry and has given him opportunities of judging the needs and capabilities of young men in training for routine work and for research in electrical engineering. In the 1938-39 session, Dr. Dannatt was part-time lecturer in electrical engineering at Queen Mary College, University of London. Prof. Goodlet, who only took office in November last, resigned in order that he might make more effective use of his capacity in war-work elsewhere.

\section{Books in War-time}

IN NATURE of May 11, p. 719, we put forward the plea that books should not be subject to the proposed purchase tax. It has now been announced that on June 21 the Chancellor of the Exchequer received a deputation in this connexion composed of representatives of the church, literature, science, and education. The deputation consisted of theArchbishop of Canterbury (who introduced the deputation), Sir Arthur Eddington, Lord Hambleden, Mr. A. P. Herbert, M.P., Prof. A. V. Hill, Dr. Albert Mansbridge, Mr. J. B. Priestley, Sir Charles Grant Robertson, and Prof. R. H. Tawney. The Bishop of Chichester and Sir Will Spens were unavoidably prevented from attending. The deputation was accompanied by Mr. Geoffrey Faber and Mr. G. Wren Howard, president and vice-president of the Publishers' Association, and Mr. Stanley Unwin, chairman of the Books and Periodicals Committee of the British Council.

\section{Pest Control Chemicals}

AT a recent meeting of interested firms, the Pest Control Chemicals Export Group was formally inaugurated, with headquarters at 166 Piccadilly, London, W.1. The Group has now received the recognition of the Export Council of the Board of Trade. The broad object of the Group is to promote the export trade in such chemicals. Any British persons, firms or bodies corporate actively engaged in the manufacture and export of pest control chemical products, such as $(a)$ disinfectants, (b) sheep and cattle dips, (c) agricultural insecticides and fungicides and $(d)$ animal medicines and allied products are eligible for membership of the Group. The main Group comprises four autonomous sub-groups to deal with the problems arising from each of these sections of the industry. Thirty-six firms have already signified their intention of joining the Group. The first problems of the Group will be in connexion with materials in short supply.

\section{Evulsion of Front Teeth in East Africa}

In reference to recent comment in Nature (April 20 , p. 631 ) on Dr. Aleš Hrdlička's study of the practice of removing the front teeth found among primitive peoples, Dr. Frank Marsh, c/o Anglo-Iranian Oil Co., Ltd., Pathological Laboratory, Abadan, Iran, suggests an alternative to the ritual origin of the custom, based upon his experience in British East Africa. There, he points out, the practice of removing the incisors is almost entirely confined to the Masai and related tribes. These tribes are warrior castes who under their natural (pre-controlled) condition lived by and for fighting; and in the course of this pursuit they expected to receive wounds, especially from arrows carrying poison derived from putrescent flesh. The juices of putrefaction contain large numbers of the spores of Clostridium tetani, causing lockjaw. The victim is then fed on milk and other liquids introduced through the toothless gap. Some recover-a result rare among civilized peoples. Dr. Marsh suggests that this may be a definite practical reason for the ritual removal of the teeth.

While it is unquestionable that practical experience of the kind to which Dr. Marsh refers would tend to perpetuate the practice in a given group of people, its influence probably is secondary. Various reasons are given by peoples who follow the practice; for example, it may be related to the escape of the soul from the body at death; while it is too widely distributed in time and space-it occurs among the mesolithic peoples of Palestine and North Africa-for it to be likely that a single practical purpose is implicated in all the varying conditions alike.

\section{The Populations of Southern Algeria}

Dr. MaUrice Gronier devotes his inaugural thesis (Thèse de Paris, No. 163 ; 1940) to the anthropological features and peculiarities of disease of the inhabitants of southern Algeria. The Arab population is characterized by a fairly high average stature, distinct dolichocephaly and leptorhinia, while the Mzabite population is distinguished by a higher stature, a relatively long trunk, a tendency to mesocephaly and a higher nasal index. The dentition of these populations is remarkably good, there being an exceedingly low percentage of caries. In addition to widespread malaria, parasitic invasion of the skin and alimentary canal and especially trachoma, the points in which the natives of southern Algeria show a striking contrast with Europeans are as follows : 
the absence of the nervous complications of syphilis in spite of the prevalence of that disease, the low incidence of diseases of the liver, the rarity of appendicitis, the frequency of pain in the region of the solar plexus, the prevalence of the osteo-articular and glandular forms of tuberculosis and the frequency of cataract in elderly persons.

\section{Euthanasia}

IN the April issue of the Quarterly Review, Sir Arthur Hurst discusses the question of euthanasia from a practical point of view without any sentimental considerations. Those in favour of the practice, he points out, maintain that euthanasia should only be carried out on persons who are affected with an incurable and painful disease, which cannot be controlled by any form of treatment. On the other hand, the cases in which euthanasia appears most desirable do not come within the scope of the Euthanasia Act, which requires the expressed desire of the patient that his life should be ended. Such cases are those of new-born babies with severe deformities or conditions preventing normal mental development, or that of the intelligent man who becomes paralysed and is unable to communicate his wishes by speech or writing.

Sir Arthur condemns the unjustifiable confidence displayed by the advocates of euthanasia in the ability of two independent medical advisers, however experienced they may be, to decide whether a disease is incurable, and quotes several examples of patients condemned to death by eminent physicians or surgeons making an unexpected and complete recovery. In undoubted cases of incurable and painful disease, in which no relief can be obtained except by morphia, Sir Arthur recommends that the patient should be kept permanently free from pain by gradually increasing the dose and giving the injections as often as is necessary. Moreover, pain can be controlled not only by drugs but also by surgical operation, which is particularly indicated when the painful disease is not likely to be rapidly fatal and the administration of morphia is therefore undesirable.

\section{Photo-cell Applications in the Foodstuffs Industries}

IN commerce the difference between one quality of rice and another consists mainly in the proportion of discoloured grains present. Since hand-sorting has never been commercially practicable, the mechanical and electrical method of sifting out the discoloured grains by a machine, described in a paper by $\mathrm{A}$. Seymour in the Electrical Times of June 6, may have far-reaching effects. The machine utilizes the properties of a photo-cell. By. an ingenious mechanical method, the grains emerge from the feeder in a single line at a speed of $5 \mathrm{ft}$. per sec. and pass under the electric 'eye'. The perfect grains shoot straight forward into a tube leading downwards to a sack. Discoloured grains cause an electrical impulse through the photo-electric cell; this brings into action a jet of compressed air, which sends them into another receptacle.

Examination of granulated sugars is more elaborate, as it includes a classification of the finished sugars for general appearance and an evaluation of the colour and turbidity of the sugar solutions. Experiments with photo-electric apparatus have shown that good correlation exists between the appearance of a sample of granulated sugar and its reflectance relative to magnesium oxide. A specially designed optical system in the photo-electric apparatus permits measurements of the transmittancy of sugar solutions as well as of the reflectance of the sugar in granulated form. Numbers obtained from these data enable the expert to compare the relative merits of the samples.

\section{The Edinburgh Botanic Garden}

A PAper by John M. Cowan (J. Roy. Hort. Soc., 65, Pt. 3 ; March 1940) describes the various botanical personalities who have contributed thought and organization to the development of the Royal Botanic Garden, Edinburgh. This is one of the oldest 'physic' gardens in Britain, and was established in 1670 by Robert Sibbald, with help from his friends Andrew Balfour and Patrick Murray. The first 'intendant' was James Sutherland, whose subsequent appointment as the first professor of botany at the University of Edinburgh ensured that close co-operation between academic plant science and practical horticulture which has been so marked a feature of the institution throughout its history. The Prestons, Charles Alston and John Hope succeeded. Sutherland, each adding patiently a solid quota of work. Rutherford, discoverer of nitrogen, was also in charge of the garden, and more recently, J. Hutton Balfour and Sir Isaac Bayley Balfour have enhanced the reputation of the garden as an academic centre. It now possesses modern laboratories, and provides a stimulating part of the curriculum for students in medicine, arts, pure science, forestry and agriculture.

\section{Road Obstruction Lanterns}

THE General Electric Co., Ltd., has developed a road obstruction lantern which complies strictly with the Lighting (Restrictions) Order, 1940. The use of these electric lanterns for fixing to street bollards or other supports has many advantages. Not only does it mean a saving ranging from $2 d$. to $6 d$. per lamp per day, but it also saves in oil and man-power. According to Roads and Road Construction of June 1, in one London borough alone the saving effected in this way amounts to nearly $£ 5,000$ a year. The G.E.C. lantern is constructed of lead-coated sheet steel and has three sides, stencilled with the approved St. Andrew's Cross sign and backed with white opal glass. Inside are a detachable baffle and a B.C. lampholder for use with a I5-watt pearl Osram lamp. This provides the correct amount of light $(0.5$ candle per square foot) on the crosses. The lamp is easily accessible for wiring and maintenance. The lantern is supplied finished with either black or white outside. A two-lamp unit is preferred by some authorities because of the advantages of ensuring that there is a light on the island even if one lamp fails. The cost of the G.E.C. two-lamp lantern is little greater than that of the standard unit. 